Available online at http://jurnal.goretanpena.com/index.php/JSSR

\title{
PEMBUATAN ANIMASI 3D USAHA KECIL MENENGAH (BENGKEL)
}

\author{
Novi Rahayu ${ }^{1}$, Ginanjar Saputra ${ }^{2}$ \\ ${ }^{1}$ Sekolah Tinggi Ilmu Administrasi, Bengkulu \\ ${ }^{2}$ Fakultas Teknik Universitas Muhammadiyah, Bengkulu \\ e-mail: novierahayu1980@gmail.com ${ }^{1}$, ginanjarsaputra@gmail.com²
}

\begin{abstract}
Motorcycle repair shop is a business that is increasingly popular and more and more people are deciding to pursue this business considering that the profits generated in this business are quite promising. This is in line with the increasing demand for motorized vehicles and cars. Over time, people have started to need services, this of course takes time and of course the funds needed must meet the needs for repairs. However, if you look at the promotion methods carried out by the developers to the community, it is still fairly traditional, namely by showing a sheet of paper containing writing on services and people's talk which is still in the form of a brochure. This of course will make it difficult for prospective customers to know the location of the workshop and the quality of the workshop, and this will indirectly cause doubts for prospective buyers to decide to repair the motorbike. If you look at current technological developments, where $3 \mathrm{D}$ animation is suitable to be applied and become a promotional tool
\end{abstract}

Keywords: Blender application, Adobe Premiere.

\begin{abstract}
Abstrak: Bengkel motor adalah bisnis yang semakin digemari dan Semakin hari semakin banyak yang memutuskan untuk menekuni bisnis ini mengingat keuntungan yang dihasilkan pada bisnis ini cukup menjanjikan. Hal ini sejalan dengan kebutuhan kendaraan bermotor dan mobil makin meningkat. Seiring berjalannya waktu, masyarakat sudah mulai membutuhkan jasa servis, hal ini tentu membutuhkan waktu dan tentunya dana yang diperlukan harus memenuhi kebutuhan untuk perbaikan. Namun, jika dilihat pada metode promosi yang dilakukan para pengembang kepada masyarakat masih terbilang tradisional, yaitu dengan memperlihatkan selembaran kertas yang berisi tulisan jasa servis dan omongan atar orang yang masih berbentuk brosur. Hal ini tentunya akan menyulitkan calon pelanggan untuk mengetahui lokasi bengkel dan kualitas bengkel tersebut, dan hal ini secara tidak langsung akan menimbulkan keraguan pada calon pembeli untuk memutuskan memperbaiki motor tersebut. Jika melihat perkembangan teknologi saat ini, dimana animasi 3D cocok untuk diterapkan dan menjadi alat promosi.
\end{abstract}

Kata kunci: Aplikasi blender, Adobe Premiere.

\section{PENDAHULUAN}

Multimedia tentunya sudah tidak asing terdengar oleh manusia, apalagi multimedia memegang peranan penting didalam kehidupan sehari-hari. Multimedia hampir bisa digunakan pada semua bidang, dengan perkembangan teknologi yang sangat pesat sekarang ini memungkinkan multimedia selalu hadir dan menjadi kebutuhan setiap orang.
Di mana bengkel motor adalah bisnis yang semakin digemari dan. Semakin hari semakin banyak yang memutuskan untuk menekuni bisnis ini mengingat keuntungan yang dihasilkan pada bisnis ini cukup menjanjikan. Hal ini sejalan dengan kebutuhan kendaraan bermotor dan mobil makin meningkat. Seiring berjalannya waktu, masyarakat sudah mulai membutuhkan jasa servis motor, hal ini tentu membutuhkan waktu dan 
Available online at http://jurnal.goretanpena.com/index.php/JSSR

tentunya dana yang diperlukan harus memenuhi kebutuhan untuk perbaikan. Namun, jika dilihat pada metode promosi yang dilakukan para pengembang kepada masyarakat masih terbilang tradisional, yaitu dengan memperlihatkan selembaran kertas yang berisi tulisan jasa servis dan masih berbentuk brosur. Hal ini tentunya akan menyulitkan calon pelanggan untuk mengetahui lokasi bengkel dan kualitas bengkel tersebut, dan hal ini secara tidak langsung akan menimbulkan keraguan pada calon pembeli untuk memutuskan memperbaiki motor tersebut. jika melihat perkembangan teknologi saat ini, dimana animasi 3D cocok untuk diterapkan dan menjadi alat promosi.

Dengan adanya teknologi animasi ini calon pelanggan dapat mengetahui bentuk ruko, dan fasilitas yang diminati tanpa harus datang ke lokasi. atas dasar inilah penulis berencana untuk membuat animasi 3D untuk diterapkan pada brosur bengkel, sehingga dengan adanya animasi ini diharapkan dapat membantu memudahkan pemilik bengkel untuk melakukan proses promosi dan memungkinkan calon pelanggan untuk dapat mengetahui fasilitas dan ruko tanpa harus ke lokasi rumah tersebut, sehingga masyarakat menjadi lebih yakin untuk memperbaiki motornya yang rusak.

Animasi adalah gambar bergerak berbentuk dari sekumpulan objek (gambar) yang disusun secara beraturan mengikutin alur pergerakan yang telah ditentukan pada setiap pertambahan hitungan waktu yang terjadi. Gambar atau objek yang dimaksud dalam definisi di atas bisa berupa manusia, hewan maupun tulisan.

Animasi sebagai proses
penciptaan efek gerak atau efek perubahan bentuk yang terjadi selama beberapa waktu. Animasi juga merupakan suatu teknik menampilkan gambar berurut sedemikian rupa sehingga penonton merasakan adanya ilustrasi gerakan (motion) pada gambar yang ditampilkan. Definisi lain dari animasi adalah penggunaan komputer untuk menciptakan gerak pada layar. Selain itu animasi merupakan sumber utama untuk melakukan aksi dinamis dalam suatu presentasi multimedia. (Djalle Zaharuddin 2016)

\section{MULTIMEDIA}

Istilah multimedia berkenaan dengan penggunaan berbagai jenis/bentuk media secara berurutan maupun simultan dalam menyajikan suatu informasi. pengertian multimedia merupakan kombinasi dari berbagai jenis media seperti teks, grafik, suara, animasi dan video dalam aplikasi computer. (Unik Ambar Wati, dkk 2010)

Multimedia merupakan kombinasi teks, seni, suara, animasi, dan video yang disampaikan kepada seorang (peserta didik) dengan komputer atau peralatan manipulasi elektronik dan digital yang lain. Melalui gabungan media-media ini pengalaman belajar menjadi sesuatu yang interaktif yang mencerminkan suatu pengalaman dalam kehidupan sehari-hari.

Komponen penting multimedia yaitu:

1 harus ada komputer yang mengkoordinasikan apa yang dilihat dan didengar, yang berinteraksi dengan pengguna,

2 harus ada link yang menghubungkan kita dengan informasi,

3 harus ada alat navigasi yang memandu pengguna menjelajah jaringan informasi,

4 multimedia menyediakan tempat kepada pengguna untuk mengumpulkan, memproses, mengomunikasikan informasi dan ide.

\section{VIDEO}

Menurut kausar, ahmad dkk (2015) Istilah video berasal dari bahasa latin yaitu dari kata vidi atau visum yang artinya melihat atau mempunyai daya penglihatan. Dalam kamus bahasa indonesia adalah teknologi pengiriman sinyal elektronik dari suatu gambar 
Available online at http://jurnal.goretanpena.com/index.php/JSSR

bergerak. Video adalah teknologi perekaman, pengolahan, penyimpanan, pemindahan, dan perekonstruksian urutan gambar diam dengan menyajikan adeganadegan dalam gerak secara elektronik video menyediakan sember daya yang kaya dan hidup bagi aplikasi multimedia. Video merupakan gambar yang bergerak. Jika objek pada animasi adalah buatan, maka objek pada video adalah nyata. Video sebagai media digital yang menunjukkan susunan atau uraian gambar-gambar dan memberikan ilusi, gambaran serta fantasi pada gambar yang bergerak. Video juga bisa dikatakan sebagai gabungan gambar-gambar mati yang dibaca berturutan dalam waktu dengan kecepatan tertentu. Gambargambar yang disebut dengan frame rate, dengan satuan fps (frame per second). Karena dimainkan dalam kecepatan yang tinggi maka tercipta ilusi gerak yang halus, semakain besar nilai frame rate maka akan semakin halus pergerakan yang ditampilkan. Biasanya menggunakan film seluloid, sinyal elekronik atau media digital.

\section{BLENDER}

Blender merupakan software pengolah 3 dimensi (3D) untuk membuat animasi 3D, yang bisa dijalankan di windows, macintosh dan linux. Blender juga sama seperti software 3D pada umumnya seperti 3DS Max, maya dan lightwave, tetapi juga mempunyai perbedaan yang cukup mendasar seperti projek kerja di blender bisa dikerjakan dihampir semua software 3D komersial lainnya, tampilannya yang bisa diatur sesuka hati, mempunyai simulasi physics yang baik dan menggunakan uv yang lebih mudah. Blender juga dapat membuat game karena memilik Game Engine. (Rori, Jinifer dkk 2016)

Menurut Kresno Murti Mulyono dan Hanif Al Fatta (2012) Blender adalah merupakan sebuah software pemodelan animasi 3D yang memiliki fiture game engine, Blender pada awalnya di kembangkan oleh perusahaan animasi Belanda NeoGeo sebagai program animasi internal, Blender tumbuh dan berkembang bersama proyek yang di kerjakan NeoGeo. Kemudian tidak lama setelah versi geratis di publis di internet, NeoGeo tidak lagi menalankan bisnisnya. Pada saat itu Ton Roosendaal, "Bapak" dari blender dan programmer utama, membuat perusahaan yang bernama NOT a Number untuk mengembangkan Blender lebih jauh.

\section{FLOWCHAT}

Flowchart merupakan penyajian yang sistematis tentang proses dan logika dari kegiatan penanganan informasi atau penggambaran secara grafik dari langkahlangkah dan urut- urutan prosedur dari suatu program. Bagan alir (flowchart) adalah bagan (chart) yang menunjukkan alir (flow) di dalam program atau prosedur sistem secara logika. Bagan alir digunakan terutama untuk alat bantu komunikasi dan untuk dokumentasi. (Muslin setyo rejeki, 2013).

\section{METODE}

Pada Perancangan konsep pembuatan animasi profil pada bengkel ini diantaranya adalah mengidentifikasi audiens dan tujuan.

1. Identifikasi Audiens

Dalam video ini ditargetkan untuk masyarakat yang memperbaiki kendaraannya yang rusak.

2. Tujuan

Video ini mempermudah dan membatu untuk mempermudahkan mempromosikan bengkel kepada pelanggan.

\section{HASIL DAN PEMBAHASAN}

Tahap ini biasanya menggunakan Storyboard untuk menggambarkan deskripsi scane dengan mencantumkan video perancangan video berbasis animasi 3D sebagai berikut.

1. Scene 1, menampilkan profil 
Available online at http://jurnal.goretanpena.com/index.php/JSSR

bengkel dengan durasi 10 detik.

2. Scene 2, dalam scene pertama akan menampilakan intro awal berbentuk teks 10 detik.

3. Scene 3, scene kedua yaitu tampilan depan ruko dengan durasi 9 detik.

4. Scene 4, scene ketiga menampilkan bagian dalam ruko dengan durasi 9 detik.

5. Scene 5, scene ke empat ini menampilkan sertifikan balai latihan kerja dengan durasi 10 detik

6. Scene 6, scene kelima yaitu menampilkan posisi alat dengan durasi 9 detik.

7. Scene 7, scene keenam menampilkan suku cadang dengan durasi 9 detik.

8. Scene 8, scene ketujuh yaitu peayanan pemesanan berbagai makanan, minuman dan rokok dengan durasi 10 detik.

\section{Material Collecting}

Analisis Kebutuhan Hardware Berikut adalah perangkat keras yang dibutuhkan dalam pembuatan video : unit computer dengan spesifikasi

1. Processor dual core

2. Mainboard ECS

3. Ram 4 GBHarddisk $500 \mathrm{~GB}$

4. VGA 1 GB 128 bit 1 unit kamera DSLR

5. 1 set lighting

Analisis Kebutuhan Software Berikut adalah perangkat lunak yang digunakan dalam pembuatan videoprofil:

1. Blender adalah softwareyang digunakan untuk pembuatan animasi.

2. Adobe Premiere adalah software yang digunakan untuk mengedit dan menyatukan tiap scane sehingga menjadi video animasi

\section{Pembuatan (Assembly)}

Dalam Tahap ini pembuatan Animasi mulai dilakukan, adapun proses pembuatan animasi terdiri dari beberapa tahapan sebagai berikut:

Moddeling

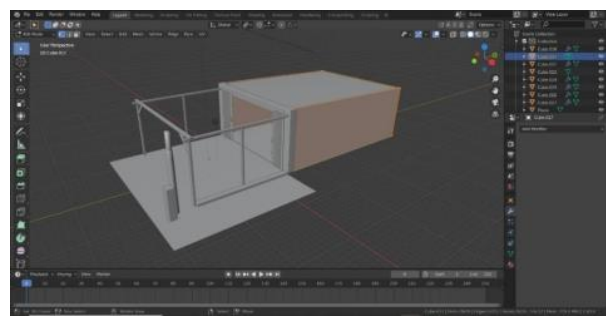

Gambar 1. Moddeling

Tahapan ini adalah awal dari sebuah proses penciptaan animasi dan pembentukan objek 3D pada bengkel ini sendiri.

Animation

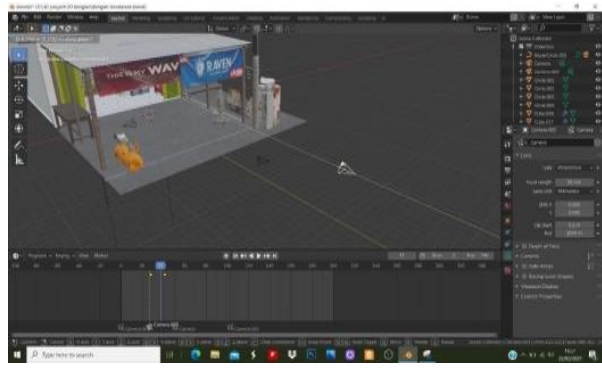

Gambar 2. Animation

Tahap ini dimana proses pembuatan animasi untuk bengkel, dimana animasi ini dapat berupa gerakan baik dimana gerak objek maupun gerak kamera untuk menciptakan animasi walktought.

\section{Texturing}

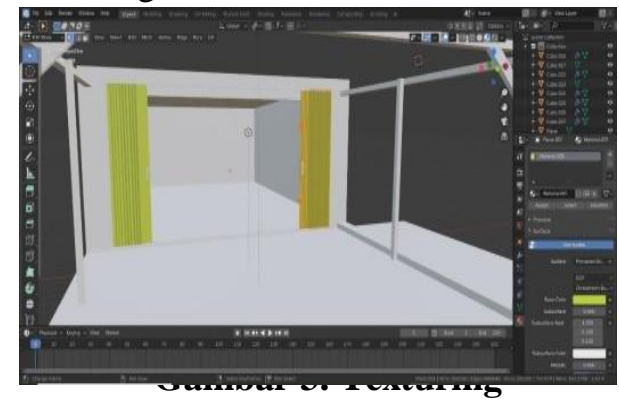

Pada tahap ini setelah objek 3D selesai dibuat, maka proses selanjutnya adalah memberikan material atau texture dan warna untuk objek tersebut sehingga 
Available online at http://jurnal.goretanpena.com/index.php/JSSR

akan tampak suatu kesatuan yang nyata.

Lighting

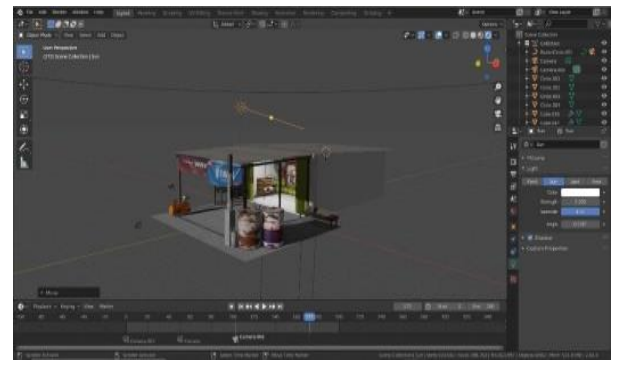

Gambar 4. Lighting

Proses ini adalah proses pembuatan dan pemberian cahaya sehingga diperoleh kesan visual yang realistis.

Render Animasi

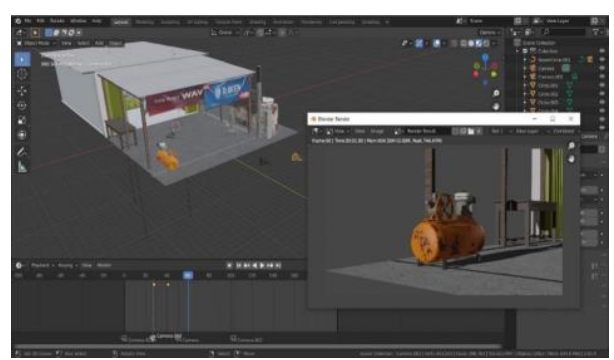

\section{Gambar 5. Render Animasi}

Proses ini adalah proses terakhir dalam pembuatan di mana pengkalikualasian pada 3D yang telah di berikan texture, lighting dan animasi. Dengan demikian hasil yang didapatkan menjadi sangat bagus.

Vocal audio

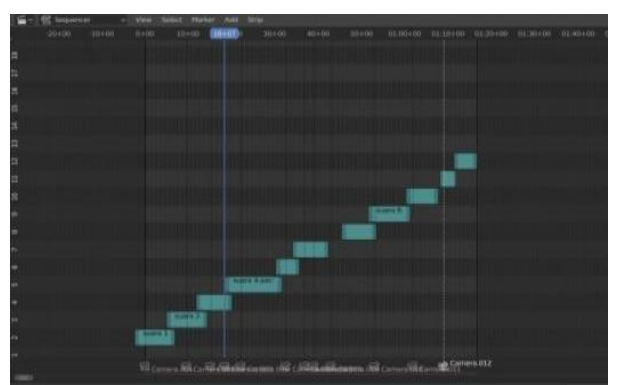

Gambar 6. Vokal audio

Proses ini adalah proses pemasukkan suara dalam video animasi sehingga lebih menarik.

Sound effect

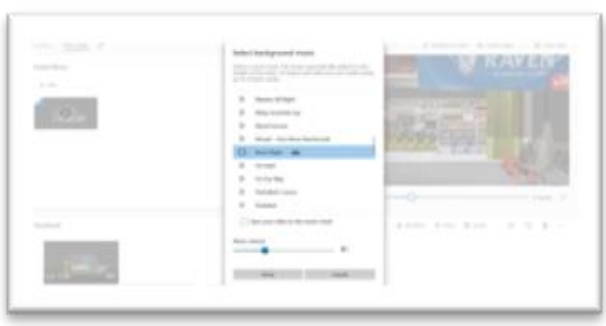

\section{Gambar 7. Sound effect}

Dalam proses ini adalah pemasukan sound tambahan dalam video seolah lebih nyata dan memberikan tekanan pada sebuah adegan akan membangun kesan lebih dalam bagi penonton.

\section{Composting}

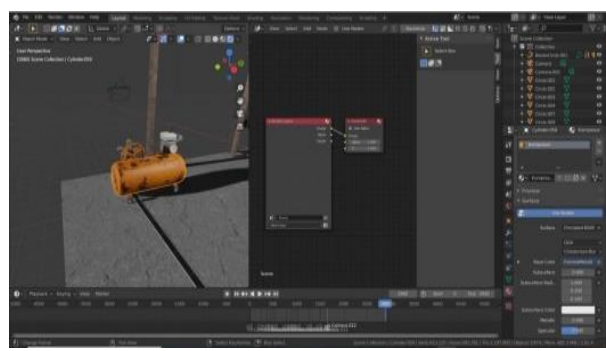

Gambar 8. Composting

Dalam proses ini adalah proses di mana proses untuk menggabungkan kembali objek yang telah dipisah pisahkan pada tahap sebelumnya.

Finising

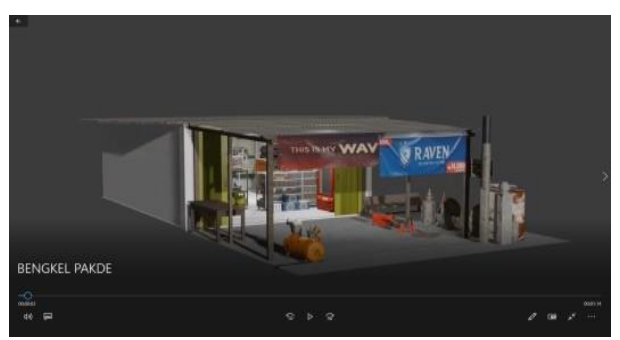

Gambar 9. Finising

Dalam proses ini di mana proses terakhir dalam pembuatan animasi dalam bentuk 
Available online at http://jurnal.goretanpena.com/index.php/JSSR

video sehingga kita bias melihat yang telah di buat.

\section{SIMPULAN}

Pembuatan Video Promosi Usaha Kecil Menengah (Bengkel) ini telah berhasil dirancang dengan menggunakan Blender 3D dan Adobe Premiere Pro.

Pembuatan Video Promosi Usaha Kecil Menengah (Bengkel) Berbasis Animasi Tiga Dimensi (3D) ini bertujuan untuk memberikan informasi tentang Bengkel

Desain dan pembuatan Usaha Kecil Menengah (Bengkel) dibuat semirip mungkin dengan aslinya supaya dapat menyampaikan informasi secara fakta.

4.Animasi ini sangat baik digunakan sebagai promosi karena menghemat waktu

\section{DAFTAR PUSTAKA}

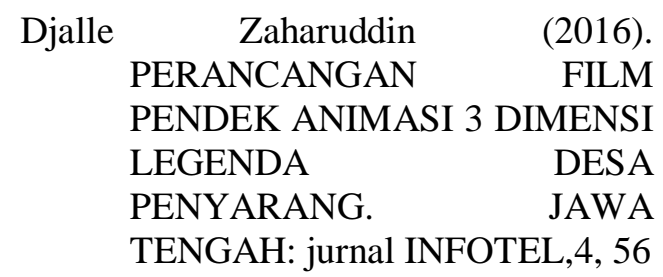

Guines purnawi, rona dkk (2013). PERANCANGAN DAN PEMBUATAN ANIMASI 2D "KERUSAKAN

LINGKUNGAN" DENGAN TEKNIK MASKIN. Jurnal imiah dasi, 14, 54-57.

Kausar, Ahmad dkk (2015). PERANCANGAN VIDEO COMPANY PROFILE KOTA SERANG DENGAN TEKNIK EDITING MENGGUNAKAN ADOBE PREMIER PRO CS 5, Jurnal PROSISKO, 2, 19-25.

Khoirudin, thoat \&murinto (2018). VISUALISASI 3 DIMENSI PERUMAHAN SEBAGAI MEDIA INFORMASI PEMASARAN (STUDI KASUS GRIYA TAMAN SRAGO KLATEN), Jurnal Sarjana Teknik
Informatika. 6, 54.

Kresno Murti Mulyono dan Hanif Al Fatta (2012). PEMBUATAN GAME LABIRIN DENGAN MENGGUNAKAN BLENDER 3D. STMIK AMIKOM Yogyakarta:Jurnal DASI.1, 12

Muslim Setyo Rejeki, A. T. (2013). MEMBANGUN APLIKASI AUTOGENERATE SCRIPT KE FLOWCHART UNTUK MENDUKUNG BUSINESS PROCESS REENGINEERING. Jurnal Sarjana Teknik Informatika.

Oka cipthadi, k (2017). VISUALISASI ANIMASI 3D SEBAGAI PROMOSI PRODUK DESAIN INTERIOR PADA PERUSAHAAN $8^{\circ}$ SOUTH KITCHEN \& HOME CABINETRY MANUFACTURER,Stmik Stikom Bali.

Pramudiar, $r$ dkk (2016). ANALISIS DAN IMPLEMENTASI MEL SCRIPT UNTUK LIGHTING DAN RENDERING PADA FILM ANIMASI 3D ROBOCUBE. Komputa, 1, 2734.

Rori, jenifers dkk (2016). PERANCANGAN APLIKASI PANDUAN BELAJAR PENGENALAN ORTODONSIA MENGGUNAKAN ANIMASI 3D, Teknik Informatika. 8, 47-51.

Sukirman (2017). PERANCANGAN ANIMASI TIGA DIMENSI MENGGUNAKAN PERANGKAT LUNAK BLENDER DI CABANG MUHAMMADIYAH

KARTASURA, WARTA LPM. 2, 67-73

Syahfrizal, agusdi dkk (2018). APLIKASI PENGENALAN TEMPAT WISATA PROPINSI BENGKULU MENGGUNAKAN 
Available online at http://jurnal.goretanpena.com/index.php/JSSR

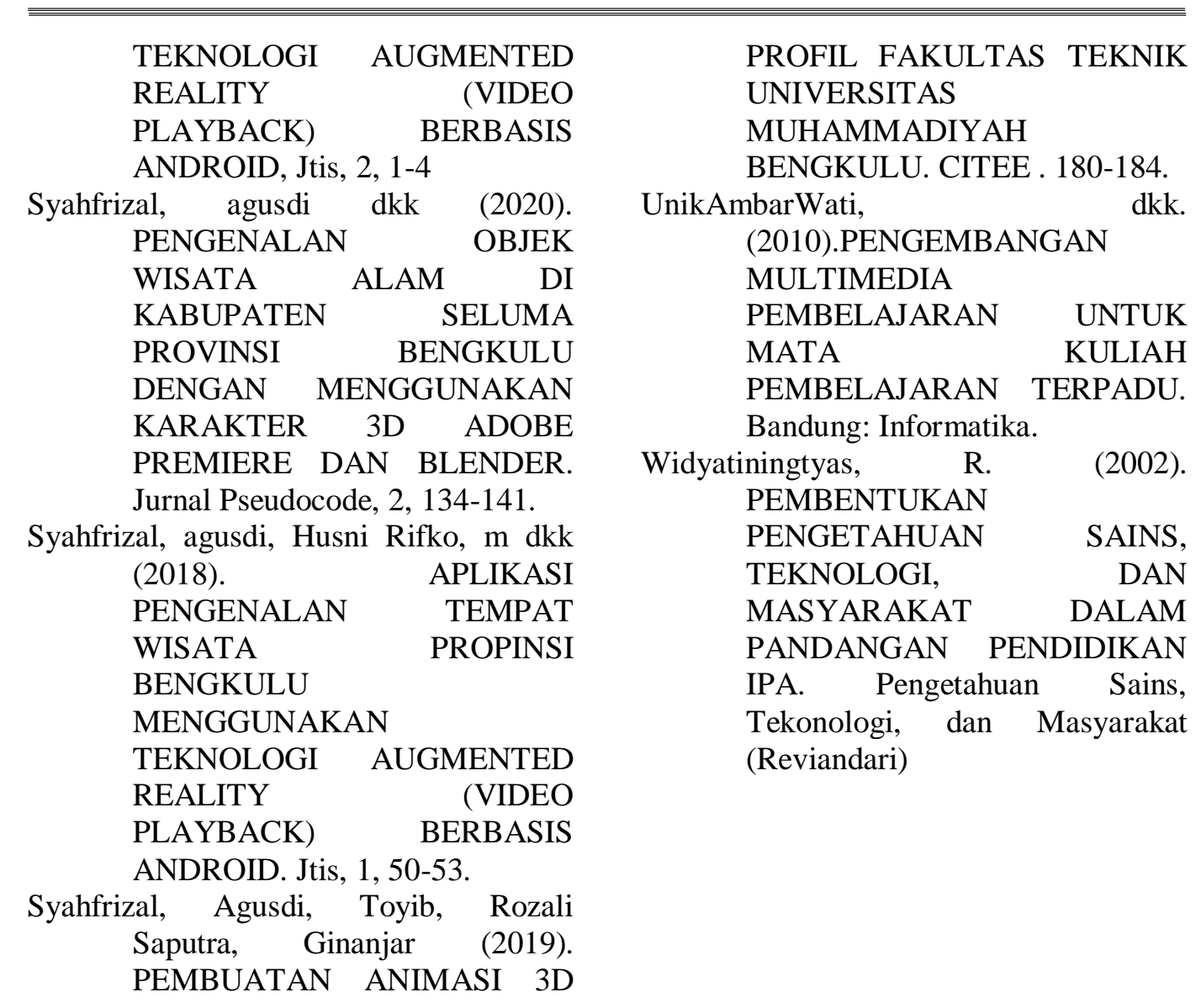

